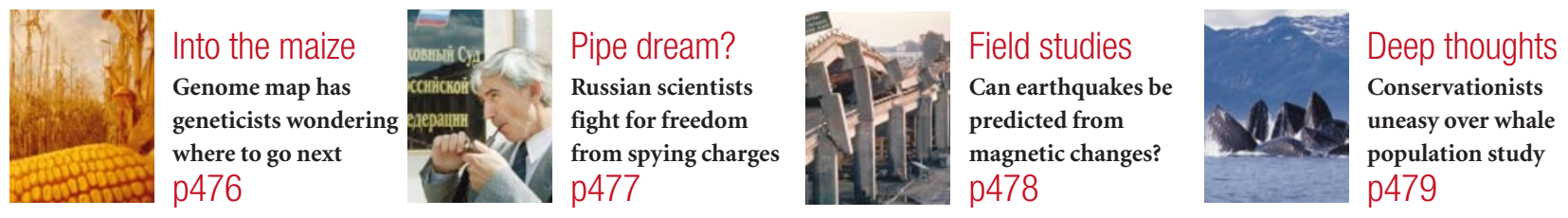

\title{
Expert panel retreats from major restructuring in blueprint for NIH
}

\section{Erika Check, Washington}

The US National Institutes of Health (NIH) should be reorganized so that it can support high-risk, pathfinding research more effectively, says an eminent group of scientists and public-policy experts in what is likely to be an influential report.

The study was commissioned by Congress and carried out by the Institute of Medicine, part of the US National Academies (see Nature 418, 572; 2002). It says that the director of the NIH should be given a formal role in the process of changing the number of institutes and centres - a switch from the present arrangement in which Congress takes the lead.

The authors also recommend that Congress should transfer the power to hire and fire institute directors from the secretary of the Department of Health and Human Services to the NIH director. In addition, they propose that Congress should give the director an annual fund of between $\$ 100$ million and $\$ 1$ billion for a programme to support "high-risk, innovative projects".

But the authors, who released their proposals on 29 July, stopped short of endorsing the sweeping changes that some observers



Overall control: the US National Institutes of Health may be given greater autonomy.

had anticipated, such as the regrouping of the NIH's 27 institutes and centres into clusters based around body systems, such as the brain.

Some of the report's proposals are likely to prove controversial. The 21-member panel, chaired by Harold Shapiro, former president of Princeton University, recommends merging the National Human Genome Research Institute, which has finished its major research goal, with the

\section{Strategy for climate research gets cool response}

Geoff Brumfiel, Washington

A much-criticized plan for guiding US research into climate change has been issued in its final form by the Bush administration. Many climate scientists say that it has been improved, but that a fundamental flaw remains - the plan lacks the budget and mechanisms to ensure that its results influence policy-making.

The strategy, unveiled on $24 \mathrm{July}$, is designed to coordinate research in important aspects of climate, such as sources and sinks in the carbon cycle and human influence on climate. Since the draft form was issued last November, it has been disparaged by many scientists, who say it ignores studies showing that climate change could damage the US economy and environment (see Nature 420, $110 ; 2002$ ) and lacks a consistent framework to guide research.

Many changes have been made, and the report is now almost twice its original length, says James Mahoney, deputy administrator of the National Oceanic and Atmospheric Administration in Washington DC, who coordinated the report. Additions include five goals designed to guide research, including a focus on ecosystem response to climate change and past climate variability. The plan also calls for 20 reports over the next four years to provide guidance for politicians. "This is an intellectually sound document," says Mahoney.

Critics agree that the plan is more cohesive, but fear that the report will have little influence on politicians. "It's not just a question of science any more," says James White, who chairs the Environmental Studies Program at the University of Colorado in Boulder. White says that the community needs to be talking to policymakers about lessening climate change, not just issuing white papers.

Ultimately, budgets are the most pressing issue, adds Benjamin Preston, a senior scientist at the Pew Center on Global Climate Change in Arlington, Virginia. US funding for climate science is currently stagnating at about $\$ 1.7$ billion annually. Without fresh funds, much of the research in the plan will be impossible, he says. 
National Institute of General Medical Sciences. It also suggests re-evaluating the special status accorded to the National Cancer Institute, which has an unusual degree of independence from the NIH director.

Many researchers, including former NIH director Harold Varmus, have been calling for greater consolidation, claiming that the current arrangement of the $\mathrm{NIH}$ makes it inflexible and causes disparities in research funding. But changes to the status of individual institutes are likely to be opposed by lobbying groups and research organizations linked to the areas of science involved. The report's authors say such difficulties mean that further mergers would be politically impractical.

"Our discussions, correspondence and meetings made it quite clear that there would be very little agreement among these communities on what the right way to organize NIH is," the report's authors write, "and there would probably be dozens of conflicting ideas in play and few clear avenues for narrowing these down."

The authors also address the ongoing effort by the Department of Health and Human Services to centralize or outsource various NIH functions, such as some aspects of grant review. This move won the authors praise from the community for attempting to defend the NIH against interference from Congress and the Bush administration. David Baltimore, president of the California Institute of Technology, describes such behaviour as "gutsy". "They're taking on two big interests here - the administration and the Congress - and I think that's a very good thing," he says.

The question now is what will become of the report. A 1984 Institute of Medicine study, which included similar proposals, was not implemented by Congress. But politicians are currently more interested in the NIH than they were then. The agency is being investigated by Congress over payments to its researchers, for example. Last month, two members of Congress told NIH director Elias Zerhouni that they were beginning an investigation of payments for lectures made to NIH executives by large centres that received NIH money.

On 10 July, the investigation was expanded after an NIH programme administrator told reporters that even though he was removed from his role in 1995 , he has since been paid an annual salary of $\$ 100,000$ while doing almost no work for the agency. This, together with the fact that Congress requested the report, makes it less likely that the study will be ignored, observers say.

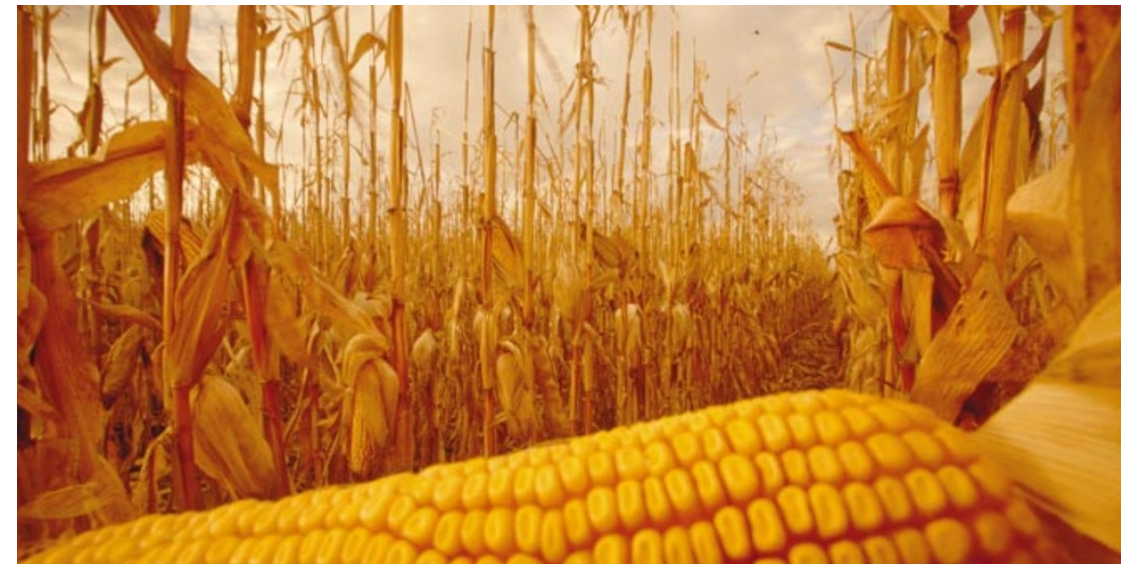

Corny question: as the maize genome map nears completion, should a full genome sequence be next?
Maize map sees geneticists split over choice of direction

\section{Carina Dennis}

Plant scientists are entering the home straight in their bid to map the genome of maize (corn, Zea mays). Weighing in at 2.5 billion base pairs, the genome is about the same size as the human version, and will be the biggest plant genome yet mapped. The data are already accelerating the discovery of useful traits, but could also provide a springboard for a more ambitious effort: the detailed sequencing of the entire maize genome.

Current work is focusing on two maps. A high-resolution genetic map, analogous to a series of signposts showing the relative positions of different genes, was made available last November.A physical map, composed of overlapping cloned gene fragments to give the distances between the genes, is nearly complete and is being combined with the genetic version to create a scaled map of gene positions.

"We have assembled about $95 \%$ of the physical map and about half of it has been anchored to the genetic map," says Ed Coe, a geneticist with the US Department of Agriculture and a director of the Maize Mapping Project. Funded by a five-year, US\$11-million grant from the National Science Foundation (NSF), the project involves scientists at the University

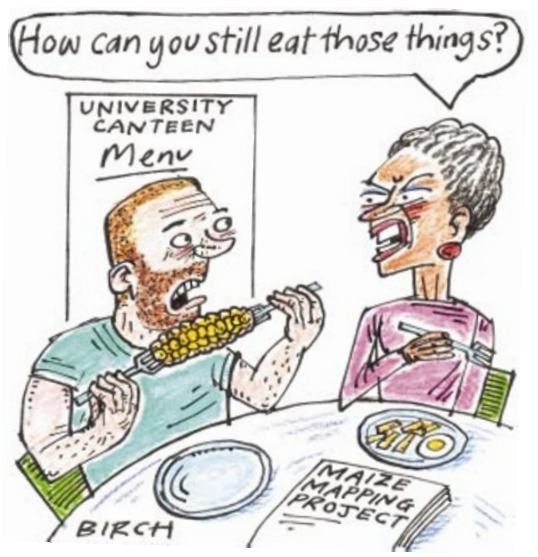

of Missouri-Columbia, where Coe is based, and the universities of Arizona and Georgia.

Project scientists predict that the integrated map will be complete in September, but it has already helped researchers. "The map has had an impact on me," says Vicki Chandler, who studies gene control at the University of Arizona. "I now know exactly what the physical distance is between my genetic markers and where my gene is," she says.

For many crop scientists, the sequence of the maize genome is the next logical step. Others disagree, pointing out that the rice genome, which is already sequenced, is similar to that of maize. They argue that the rice sequence, together with the integrated maize map, will provide a good guide for geneticists.

But certain aspects of maize biology, such as the unusual vigour of some hybrid strains, need the genome sequence to be fully understood, some researchers contend. Gene order and the number of genes vary greatly between different strains, and this may contribute to hybrid vigour. "We can't use the rice genome as a reference sequence for understanding the diversity of maize," says Joachim Messing, a maize geneticist at Rutgers University in Piscataway, New Jersey.

Some experts think it would be impractical to sequence maize and other large, repetitive cereal genomes to the same standard as rice. Last September, to address these concerns, the NSF provided $\$ 10$ million for a programme to test a gene-enriching strategy for sequencing the maizegenome. The project aims to develop a method for filtering out gene-poor areas of the genome, and to uncover ways in which the integrated map can be used to anchor data from sequencing of the gene-rich areas.

It remains to be seen what the private sector will contribute to the maize effort. Several firms, such as DuPont, based in Wilmington, Delaware, have sequenced parts of the maize genome. "At least two of the major players are interested in partnering with us," says Coe. 